\title{
PENGARUH TIGA JENIS PUPUK KANDANG DAN DOSIS PUPUK FOSFAT PADA PERTUMBUHAN DAN PRODUKSI TANAMAN CABAI (Capssicum annum L.)
}

\author{
Yudha P. K. Sinulingga, M. Syamsoel Hadi \& Yohannes C. Ginting \\ Jurusan Agroteknologi, Fakultas Pertanian Universitas Lampung \\ Jl. Prof, Soemantri Brodjonegoro, No.1, Bandar Lampung 35145 \\ E-mail:yudhasinulingga91@gmail.com
}

\begin{abstract}
ABSTRAK
Penelitian bertujuan mengetahui (1) pengaruh tiga jenis pupuk kandang (ayam, kambing, sapi) pada pertumbuhan dan produksi tanaman cabai, (2) dosis pupuk fosfat yang dapat meningkatkan pertumbuhan dan produksi tanaman cabai secara optimal, dan (3) pengaruh interaksi antara jenis pupuk kandang dan dosis pupuk fosfat pada pertumbuhan dan produksi tanaman cabai. Penelitian dilaksanakan di Kelurahan Gulak Galik, Kecamatan Teluk Betung Utara, mulai Oktober 2012 sampai Maret 2013. Pengujian analisis tanah dilakukan di BPTP Natar, Kecamatan Natar, Kabupaten Lampung Selatan. Perlakuan disusun dalam rancangan acak kelompok (rak) pola faktorial (3x5) dengan tiga ulangan. Faktor pertama adalah pupuk kandang (K), yaitu pupuk kandang ayam $\left(\mathrm{K}_{1}\right)$, pupuk kandang sapi $\left(\mathrm{K}_{2}\right)$, dan pupuk kandang kambing $\left(\mathrm{K}_{3}\right)$. Faktor kedua adalah pupuk SP-36 sebagai sumber fosfat $(\mathrm{P})$ dengan dosis $0 \mathrm{~g} \operatorname{tanaman}^{-1}\left(\mathrm{P}_{0}\right)$, dosis $10 \mathrm{~g} \operatorname{tanaman}^{-1}\left(\mathrm{P}_{1}\right), 20 \mathrm{~g} \operatorname{tanaman}^{-1}\left(\mathrm{P}_{2}\right), 30 \mathrm{~g} \operatorname{tanaman}^{-1}\left(\mathrm{P}_{3}\right)$, dan $40 \mathrm{~g} \operatorname{tanaman}^{-1}\left(\mathrm{P}_{4}\right)$. Homogenitas ragam diuji dengan uji Bartlett dan kenambahan data diuji dengan uji Tukey. Data diolah dengan Sidik Ragam dan dilanjutkan dengan uji polinomial ortogonal pada taraf uji 5\%. Hasil penelitian menunjukkan bahwa (1) pengaruh pupuk kandang ayam lebih baik dibandingkan dengan pupuk kandang sapi dan pupuk kandang kambing untuk semua variabel pengamatan, pengaruh pupuk kandang sapi tidak berbeda dengan pupuk kandang kambing, (2) pengaruh pemberian pupuk fosfat hingga dosis $40 \mathrm{~g}_{\text {tanaman }}^{-1}$ mampu meningkatkan pertumbuhan dan produksi tanaman tanaman cabai secara linear pada seluruh variabel pengamatan, (3) terdapat pengaruh interaksi pupuk kandang ayam dengan dosis pupuk fosfat, pada tinggi tanaman dan bobot kering brangkasan dosis 10, 30, dan $40 \mathrm{~g}$ tanaman $^{-1}$, pada jumlah bunga dan jumlah buah dosis 0 dan $40 \mathrm{~g} \operatorname{tanaman}^{-1}$, pada diameter buah dosis $0,10,20$, dan $40 \mathrm{~g} \operatorname{tanaman}^{-1}$, dan pada bobot buah dosis 20, 30, dan $40 \mathrm{~g}$ tanaman $^{-1}$.
\end{abstract}

Kata kunci: cabai, dosis pupuk kandang, pupuk SP-36.

\section{PENDAHULUAN}

Cabai merah (Capsicum annum L.) merupakan komoditas sayuran yang banyak digunakan masyarakat. Tidak heran bila volume pemasaran cabai semakin banyak jumlahnya. Menurut data Badan Pusat Statistika/ BPS (2011), produksi tanaman cabai Nasional mengalami penurunan selama tiga tahun terakhir. Pada tahun 2009 produksi cabai Nasional mencapai 1,42 juta ton dengan luas panen 167.123 ha dengan produktivitas sebesar 8,5 ton/ha, sedangkan pada tahun 2010 produksi cabai Nasional mencapai 1,31 juta ton dengan luas panen 160.145 ha dengan produktivitas sebesar 8,1 ton ha ${ }^{-1}$. Pada tahun 2011 produksi cabai hanya sebesar 1,29 juta ton dengan luas panen 158.987 ha dengan produktivitas 8,1 ton ha $^{-1}$.

Salah satu kendala yang dihadapi oleh petani dalam budidaya tanaman cabai adalah masalah ketesediaan hara bagi tanaman. Tanaman cabai membutuhkan pemberian unsur hara yang intensif untuk masa petumbuhan dan perkembangannya. Proses penyerapan unsur hara oleh tanaman dipengaruhi oleh banyak faktor salah satunya adalah jenis tanah. Jenis tanah berkaitan erat dengan sifat fisik, biologi, dan kimia tanah tersebut. Menurut Islami dan Utomo (1995), ketiga hal tersebut merupakan indikator ketersediaan unsur hara serta penunjang proses penyerapan unsur hara oleh tanaman yang dapat diperbaiki dengan penambahan bahan organik, salah satunya pupuk kandang.

Pupuk kandang memiliki banyak manfaat bagi tanah dan tanaman. Salah satu manfaat dari pupuk kandang adalah meningkatkan $\mathrm{pH}$ tanah. Peningkatan pH dalam tanah akan meningkatkan KTK tanah. KTK merupakan jumlah total kation yang dapat dipertukarkan pada permukaan koloid yang bermuatan negatif (Madjid, 2007). KTK Tanah merupakan sifat kimia tanah yang terkait erat dengan ketersediaan hara bagi tanaman salah satunya hara fosfor dan menjadi indikator kesuburan tanah. 
Fosfor adalah salah satu nutrisi utama yang sangat penting bagi pertumbuhan tanaman cabai. Unsur fosfor bagi tanaman berguna untuk merangsang pertumbuhan akar khususnya akar benih dan tanaman muda, membantu asimilasi, mempercepat pembungaan dan pemasakan biji (Lingga, 1999). Unsur P pada tanah Ultisols kurang tersedia bagi tanaman. Dalam mengatasi permasalahan hara $P$, pemupukan merupakan salah satu cara yang terus dilakukan untuk meningkatkan produktivitas. Disamping itu pemberian pupuk kandang merupakan kebijakan yang harus dilakukan.

Aplikasi pupuk fosfat dalam bentuk anorganik tidak ramah bagi lingkungan dan ketersediaan hara di dalamnya lambat tersedia bagi tanaman. Di lain pihak aplikasi pupuk organik seperti pupuk kandang, diharapkan dapat membantu ketesediaan unsur bagi tanaman cabai secara perlahan. Adanya asam humic di dalam pupuk organik juga diharapkan dapat mempercepat ketersediaan hara fosfor dari pupuk fosfat. Dengan demikian, aplikasi hara dari dua sumber berbeda ini diharapkan memberi pengaruh positif terhadap pertumbuhan dan produksi tanaman cabai.

Penelitian ini bertujuan untuk mengetahui (1) pengaruh tiga jenis pupuk kandang (ayam, kambing, dan sapi) pada pertumbuhan dan produksi tanaman cabai (2) dosis pupuk fosfat yang dapat meningkatkan pertumbuhan dan produksi tanaman cabai secara optimal (3) pengaruh interaksi antara jenis pupuk kandang dan dosis pupuk fosfat pada pertumbuhan dan produksi tanaman cabai.

\section{BAHAN DAN METODE}

Penelitian ini dilaksanakan di Kelurahan Gulak Galik, Kecamatan Teluk Betung Utara, Percobaan dilaksanakan pada bulan Oktober 2012 sampai Maret 2013. Pengujian analisis tanah dilakukan di BPTP Natar, Kecamatan Natar, Kabupaten Lampung Selatan.

Bahan-bahan yang digunakan adalah benih cabai varietas TM-999, pupuk kandang ayam, pupuk kandang sapi, pupuk kandang kambing, pupuk KCl, pupuk SP-36 sebagai sumber fosfat sesuai perlakuan, pupuk Urea, insektisida Pegasus 500 SC dan fungisida Antracol 70 WP, sedangkan alat-alat yang digunakan dalam penelitian ini adalah cangkul, koret, bambu, tali rafia, meteran, alat tulis, timbangan, sprayer, oven, kamera digital, dan polibag ukuran $10 \mathrm{~kg}$.

Perlakuan dalam penelitian ini ditata secara faktorial dalam rancangan acak kelompok sebanyak tiga kali ulangan. Setiap kombinasi perlakuan diwakili tiga polibag. Faktor pertama adalah pupuk kandang (K), terdiri dari pupuk kandang ayam $\left(\mathrm{K}_{1}\right)$, pupuk kandang sapi $\left(\mathrm{K}_{2}\right)$, dan pupuk kandang kambing $\left(\mathrm{K}_{3}\right)$. Faktor kedua adalah pupuk SP-36 (P) sebagai sumber fosfat dengan dosis $0 \mathrm{~g}$ tanaman ${ }^{-1}\left(\mathrm{P}_{0}\right)$, dosis $10 \mathrm{~g}^{-1 a n a m a n}{ }^{-1}$

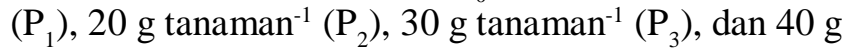
$\operatorname{tanaman}^{-1}\left(\mathrm{P}_{4}\right)$. Homogenitas ragam diuji dengan uji Bartlett dan kenambahan data diuji dengan uji Tukey. Data diolah dengan Sidik Ragam dan dilanjutkan dengan uji polinomial ortogonal pada taraf uji 5\%.

Benih cabai disemai dan setelah berumur 4 minggu (empat helai daun telah membuka sempurna) dipindahkan ke polibag berisi tanah sebanyak $8 \mathrm{~kg}$ yang telah dicampur dengan pupuk kandang (sapi, kambing, ayam) sebanyak $1 \mathrm{~kg}$ dengan pupuk SP-36 sesuai dosis perlakuan. Setelah cabai berumur satu minggu setelah tanam (mst) di polibag kemudian diberi pupuk Urea sebanyak 13,8 g tanaman $^{-1}$, pupuk $\mathrm{KCl}$ sebanyak 22,2 $\mathrm{g}$ tanaman ${ }^{-1}$.

Variabel pengamatan yang diukur adalah tinggi tanaman, tingkat percabangan, jumlah bunga, jumlah buah, bobot buah, panjang buah, diameter buah, bobot kering brangkasan, dan buah gugur tanaman.

\section{HASIL DAN PEMBAHASAN}

Data rekapitulasi pengaruh tiga jenis pupuk kandang dan dosis pupuk fosfat pada pertumbuhan dan produksi tanaman cabai (Tabel 1) menunjukkan bahwa pengaruh pupuk kandang ayam lebih baik dibandingkan dengan pengaruh pupuk kandang sapi dan pupuk kandang kambing untuk semua variabel pengamatan, kecuali tingkat cabang. Pengaruh pupuk fosfat hingga dosis $40 \mathrm{~g}$ tanaman ${ }^{-1}$ mampu meningkatkan pertumbuhan dan produksi tanaman tanaman cabai secara linear terhadap seluruh variabel pengamatan. Pengaruh interaksi antara tiga jenis pupuk kandang dengan dosis pupuk fosfat terlihat pada variabel tinggi tanaman, tingkat cabang, bobot kering brangkasan, jumlah bunga, jumlah buah, diameter buah, dan bobot buah kecuali panjang buah dan buah gugur.

Pengaruh pupuk kandang, dosis pupuk fosfat, dan interaksi antara pupuk kandang dengan dosis pupuk fosfat berbeda pada tinggi tanaman cabai (Tabel 1). Pada dosis pupuk SP-36 sebagai sumber fosfat 10; 30; dan $40 \mathrm{~g} \mathrm{tanaman}^{-1}$, pengaruh pupuk kandang ayam lebih baik masing-masing $10,26 \% ; 11,62 \%$; dan $21,27 \%$ daripada pengaruh pupuk kandang sapi dan kambing (Tabel 1). Pengaruh pupuk kandang sapi dan kambing tidak berbeda (Tabel 1).

Pemberian pupuk kandang tidak berbeda, sedangkan dosis pupuk fosfat, dan interaksi antara pupuk kandang dengan dosis pupuk fosfat berbeda pada tingkat percabangan tanaman cabai (Tabel 1). Pada pupuk 
Tabel 1. Rekapitulasi pengaruh tiga jenis pupuk kandang dan dosis pupuk fosfat pada pertumbuhan dan produksi tanaman cabai

\begin{tabular}{|c|c|c|c|c|c|c|c|c|c|}
\hline \multirow[b]{2}{*}{ Perbandingan } & \multicolumn{9}{|c|}{ Variabel pengamatan } \\
\hline & $\begin{array}{l}\text { Tinggi } \\
\text { tanaman } \\
(\mathrm{cm})\end{array}$ & $\begin{array}{l}\text { Tingkat } \\
\text { Cabang }\end{array}$ & $\begin{array}{l}\text { Bobot } \\
\text { kering } \\
\text { brangkas- } \\
\text { an (g) }\end{array}$ & $\begin{array}{c}\text { Jumlah } \\
\text { bunga }\end{array}$ & $\begin{array}{c}\text { Jumlah } \\
\text { Buah }\end{array}$ & $\begin{array}{l}\text { Diameter } \\
\text { buah } \\
(\mathrm{cm})\end{array}$ & $\begin{array}{l}\text { Panjang } \\
\text { Buah } \\
(\mathrm{cm})\end{array}$ & $\begin{array}{l}\text { Bobot } \\
\text { Buah } \\
(\mathrm{g})\end{array}$ & $\begin{array}{l}\text { Buah } \\
\text { gugur }\end{array}$ \\
\hline & \multicolumn{9}{|c|}{ Selisih $(\%)$} \\
\hline \multicolumn{10}{|l|}{ Pupuk Kandang } \\
\hline $\begin{array}{l}\mathrm{C} 1: \mathrm{k}_{1} \text { vs } \mathrm{k}_{2} \& \mathrm{k}_{3} \\
\mathrm{C} 2: \mathrm{k}_{2} \text { vs } \mathrm{k}_{3}\end{array}$ & $\begin{array}{l}10,05^{*} \\
3,60 \mathrm{tn}\end{array}$ & $\begin{array}{l}1,23 \mathrm{tn} \\
-2,07 \mathrm{tn}\end{array}$ & $\begin{array}{l}16,93^{*} \\
6,47 \mathrm{tn}\end{array}$ & $\begin{array}{l}2,62 * \\
2,79 *\end{array}$ & $\begin{array}{l}3,89 * \\
3,42 *\end{array}$ & $\begin{array}{l}2,44^{*} \\
0,44 \mathrm{tn}\end{array}$ & $\begin{array}{l}6,83^{*} \\
1,96 \mathrm{tn}\end{array}$ & $\begin{array}{l}5,92 * \\
1,42 \mathrm{tn}\end{array}$ & $\begin{array}{l}-38,18 * \\
-14,59 \mathrm{tn}\end{array}$ \\
\hline \multicolumn{10}{|l|}{ Dosis Pupuk fosfat } \\
\hline $\begin{array}{l}\text { C3 : p,Linear } \\
\text { C4 : p,Kuadratik }\end{array}$ & tn & $\begin{array}{l}* \\
\text { tn }\end{array}$ & $\begin{array}{l}* \\
\operatorname{tn}\end{array}$ & tn & tn & th & tn & tn & tn \\
\hline \multicolumn{10}{|l|}{ Interaksi } \\
\hline $\begin{array}{l}\mathrm{C} 5: \mathrm{C} 1 \text { X C3 } \\
\mathrm{C} 6: \mathrm{C} 1 \text { X C4 } \\
\mathrm{C} 7: \mathrm{C} 2 \text { X C3 } \\
\mathrm{C} 8: \mathrm{C} 2 \text { X C4 }\end{array}$ & $\begin{array}{l}* \\
\text { tn } \\
\text { tn } \\
\text { tn }\end{array}$ & $\begin{array}{l}* \\
\text { tn } \\
\text { tn } \\
*\end{array}$ & $\begin{array}{l}* \\
\text { tn } \\
\text { tn } \\
\text { tn }\end{array}$ & $\begin{array}{l}\text { tn } \\
* \\
* \\
\text { tn }\end{array}$ & $\begin{array}{l}\text { tn } \\
* \\
* \\
\text { tn }\end{array}$ & $\begin{array}{l}\text { tn } \\
\text { tn } \\
* \\
\text { tn }\end{array}$ & $\begin{array}{l}\text { tn } \\
\text { tn } \\
\text { tn } \\
\text { tn }\end{array}$ & $\begin{array}{l}* \\
\text { tn } \\
\text { tn } \\
\text { tn }\end{array}$ & $\begin{array}{l}\text { tn } \\
\text { tn } \\
\text { tn } \\
\text { tn }\end{array}$ \\
\hline
\end{tabular}

Tanggapan tanaman terhadap pupuk kandang pada taraf dosis pupuk fosfat

\begin{tabular}{|c|c|c|c|c|c|c|c|c|c|}
\hline $\mathrm{p}_{0}: \mathrm{k}_{1}$ vs $\mathrm{k}_{2} \& \mathrm{k}_{3}$ & $2,68 \mathrm{tn}$ & $-4,38 \mathrm{tn}$ & $5,16 \mathrm{tn}$ & $4,66^{*}$ & $5,98^{*}$ & $2,54 *$ & - & $-0,55 \mathrm{tn}$ & - \\
\hline $\mathrm{p}_{0}: \mathrm{k}_{2} \mathrm{vs} \mathrm{k}_{3}$ & $5,18 \mathrm{tn}$ & $-6,17 \mathrm{tn}$ & 9,99 tn & $9,66^{*}$ & $11,89^{*}$ & $2,77^{*}$ & - & $-0,34$ tn & - \\
\hline $\mathrm{p}_{1}: \mathrm{k}_{1}$ vs $\mathrm{k}_{2} \& \mathrm{k}_{3}$ & $10,26^{*}$ & $1,14 \mathrm{tn}$ & $18,57 *$ & $2,61 \mathrm{tn}$ & $1,973 \mathrm{tn}$ & $3,788^{*}$ & - & $3,295 \mathrm{tn}$ & - \\
\hline $\mathrm{p}_{1}: \mathrm{k}_{2} \mathrm{vs} \mathrm{k}_{3}$ & $13,71 *$ & $-0,01 \mathrm{tn}$ & $25,59 *$ & $2,39 \mathrm{tn}$ & $2,950 \mathrm{tn}$ & $3,101 *$ & - & $3,584 \mathrm{tn}$ & - \\
\hline $\mathrm{p}_{2}: \mathrm{k}_{1}$ vs $\mathrm{k}_{2} \& \mathrm{k}_{3}$ & $0,36 \mathrm{tn}$ & $1,11 \mathrm{tn}$ & $0,63 \mathrm{tn}$ & $0,03 \mathrm{tn}$ & 0,724 tn & $3,066^{*}$ & - & $5,306^{*}$ & - \\
\hline $\mathrm{p}_{2}: \mathrm{k}_{2}$ vs $\mathrm{k}_{3}$ & $6,99 \mathrm{tn}$ & $0,00 \mathrm{tn}$ & $12,04 \mathrm{tn}$ & $1,66 \mathrm{tn}$ & $2,046 \mathrm{tn}$ & $-1,947 \mathrm{tn}$ & - & $1,985 \mathrm{tn}$ & - \\
\hline $\mathrm{p}_{3}: \mathrm{k}_{1}$ vs $\mathrm{k}_{2} \& \mathrm{k}_{3}$ & $11,62 *$ & $3,26 \mathrm{tn}$ & $18,33^{*}$ & $0,69 \mathrm{tn}$ & $3,728 \mathrm{tn}$ & $0,682 \mathrm{tn}$ & - & $9,367 *$ & - \\
\hline $\mathrm{p}_{3}: \mathrm{k}_{2}$ vs $\mathrm{k}_{3}$ & $-1,51 \mathrm{tn}$ & $2,22 \mathrm{tn}$ & $-2,59 \mathrm{tn}$ & $0,95 \mathrm{tn}$ & $1,163 \mathrm{tn}$ & $-1,112 \mathrm{tn}$ & - & $1,241 \mathrm{tn}$ & - \\
\hline $\mathrm{p}_{4}: \mathrm{k}_{1}$ vs $\mathrm{k}_{2} \& \mathrm{k}_{3}$ & $21,27^{*}$ & $4,20 \mathrm{tn}$ & $32,28 *$ & $4,97 *$ & $6,748^{*}$ & $2,249 *$ & - & $10,749 *$ & - \\
\hline $\mathrm{p}_{4}: \mathrm{k}_{2}$ vs $\mathrm{k}_{3}$ & $-5,743 \mathrm{tn}$ & $-6,81^{*}$ & $-10,36 \mathrm{tn}$ & $-0,56 \mathrm{tn}$ & $-0,688 \mathrm{tn}$ & $-0,319 \operatorname{tn}$ & - & $0,643 \mathrm{tn}$ & - \\
\hline
\end{tabular}

Tanggapan tanaman terhadap taraf dosis pupuk fosfat pada masing-masing pupuk Kandang

\begin{tabular}{llllllllll}
\hline $\mathrm{k} 1:$ p-Linear & tn & $*$ & tn & tn & tn & $*$ & - & tn & - \\
$\mathrm{k} 1:$ p-Kuadratik & tn & $*$ & tn & tn & tn & $*$ & - & $*$ & - \\
$\mathrm{k} 2:$ p-Linear & tn & tn & tn & $*$ & $*$ & tn & - & $*$ & - \\
$\mathrm{k} 2: \mathrm{p}-$ Kuadratik & tn & tn & tn & tn & tn & $*$ & - & tn & - \\
$\mathrm{k} 3:$ p-Linear & tn & $*$ & tn & tn & tn & $*$ & - & tn & - \\
$\mathrm{k} 3:$ p-Kuadratik & tn & $*$ & tn & tn & tn & $*$ & - & $*$ & -
\end{tabular}

Keterangan: $\mathrm{p}_{0}, \mathrm{p}_{1}, \mathrm{p}_{2}, \mathrm{p}_{3}, \mathrm{p}_{4}$ berturut dosis SP-36 0, 10, 20,30 $\left(\right.$ g tanaman $\left.^{-1}\right), \mathrm{k}_{1}=$ Pupuk kandang ayam, $\mathrm{k}_{2}=$ Pupuk kandang sapi, $\mathrm{k}_{3}=$ Pupuk kandang kambing, $\mathrm{BKB}=$ Bobot Kering Brangkasan, $\mathrm{TkCb}=$ Tingkat Percabangan, $*$ = Nyata pada $\alpha: 0,05$, dan $\mathrm{tn}=$ Tidak nyata pada $\alpha: 0,05$.

kandang ayam dan pupuk kandang kambing, setiap peningkatan dosis pupuk SP-36 sebagai sumber fosfat sebanyak $5 \mathrm{~g}$ tanaman $^{-1}$ meningkatkan tingkat percabangan tanaman masing-masing sebesar 0,19 dan 0,09 cabang (Gambar 1).
Pemberian pupuk kandang, dosis pupuk fosfat, dan interaksi antara pupuk kandang dengan dosis pupuk fosfat berbeda pada bobot kering brangkasan (Tabel 1). Pada dosis pupuk SP-36 sebagai sumber fosfat 10; 30; dan $40 \mathrm{~g}_{\text {tanaman }}{ }^{-1}$, pengaruh pupuk kandang ayam lebih 
baik masing-masing 18,57\%; 18,33; dan 32,28\% daripada pupuk kandang sapi dan kambing (Tabel 1). Pengaruh pupuk kandang sapi dan kambing tidak berbeda (Tabel $1)$.

Pemberian pupuk kandang, dosis pupuk fosfat, dan interaksi antara pupuk kandang dengan dosis pupuk fosfat berbeda terhadap jumlah bunga tanaman cabai
(Tabel 1). Pada dosis pupuk SP-36 sebagai sumber fosfat 0 dan $40 \mathrm{~g}$ tanaman $^{-1}$, pengaruh pupuk kandang ayam lebih baik masing-masing 4,66\% dan 4,97\% daripada pupuk kandang sapi dan kambing (Tabel 1). Pada pupuk kandang sapi, setiap peningkatan $5 \mathrm{~g}$ pupuk SP-36 sebagai sumber fosfat meningkatkan jumlah bunga sebesar 0,7 kuntum (Gambar 2).

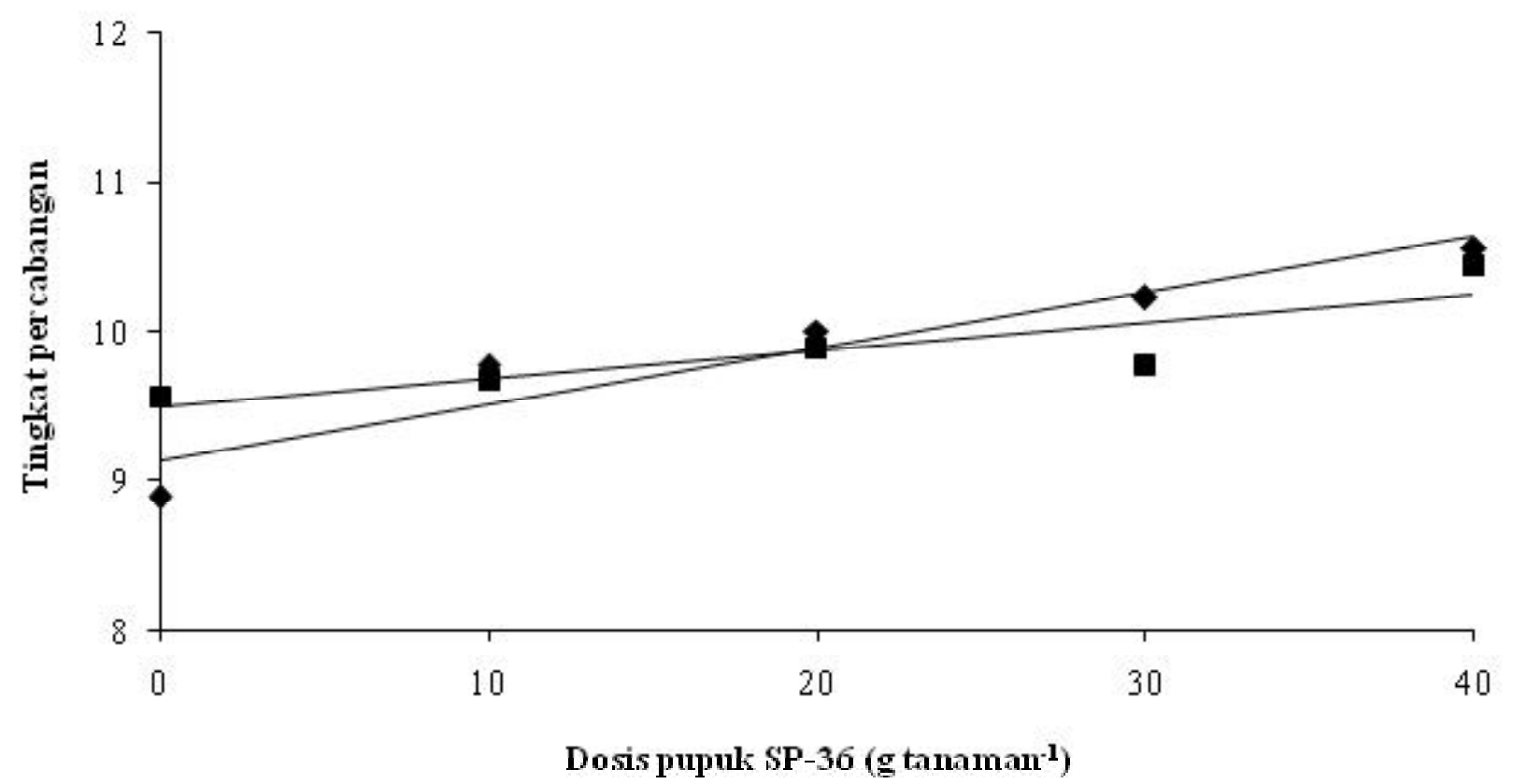

Gambar 1. Pengaruh dosis pupuk SP-36 sebagai sumber fosfat terhadap tingkat percabangan tanaman cabai pada masing-masing pupuk kandang ayam dan kambing. $\boldsymbol{\nabla}=$ pupuk kandang ayam $(\mathrm{Y}=0,19 \mathrm{x}+9,1336$, $\left.\mathrm{r}=0,95^{*}\right)$ dan $\boldsymbol{\Pi}=$ pupuk kandang kambing $\left(\mathrm{Y}=0,09 \mathrm{x}+9,4889, \mathrm{r}^{2}=0,86^{*}\right)$.

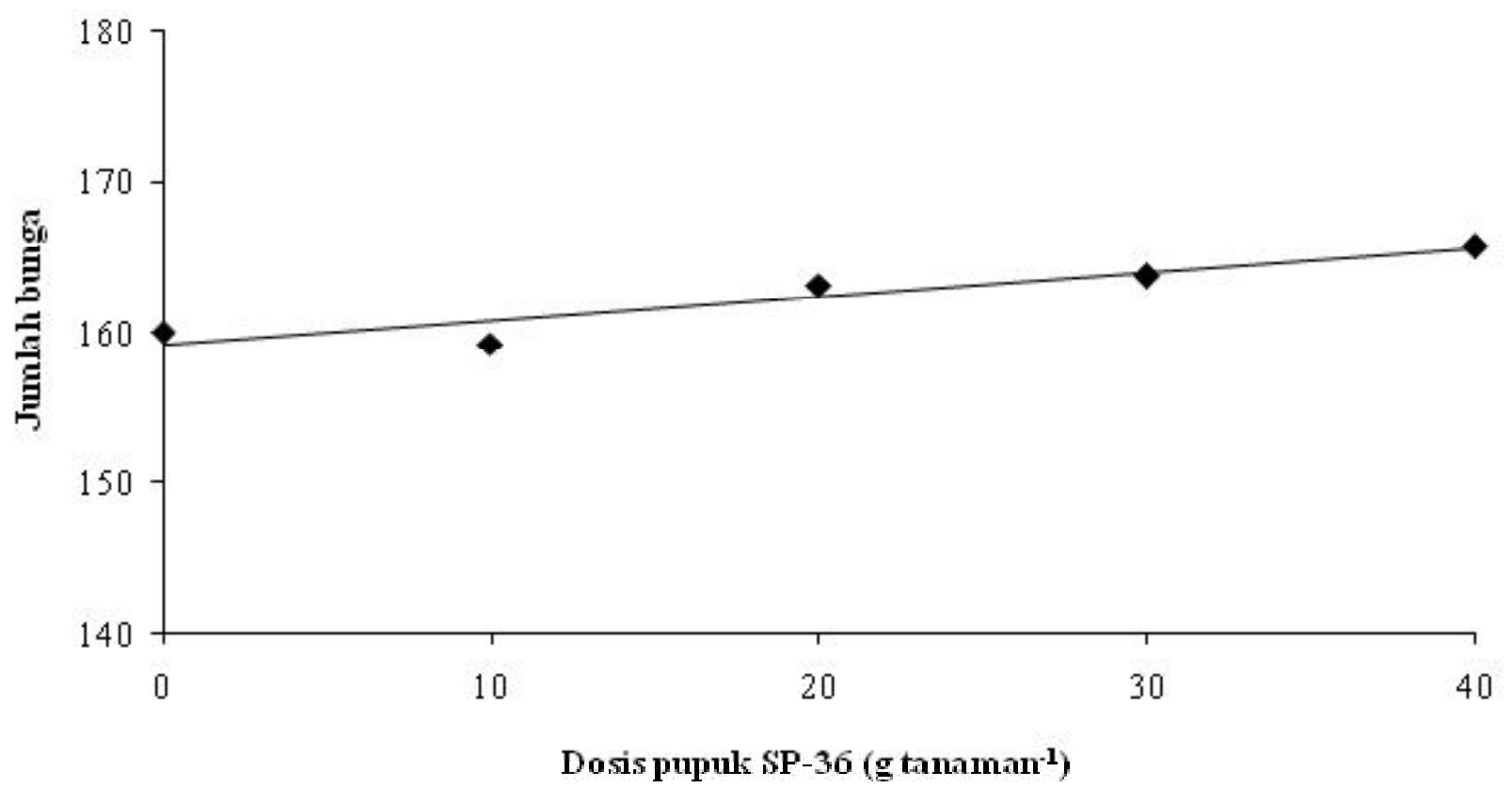

Gambar 2. Pengaruh dosis pupuk SP-36 sebagai sumber fosfat terhadap jumlah bunga tanaman cabai pada pupuk kandang sapi. $\left(\mathrm{Y}=0,7 \mathrm{x}+159,19, \mathrm{r}=0,86^{*}\right)$. 
Pemberian pupuk kandang, dosis pupuk fosfat, dan interaksi antara pupuk kandang dengan dosis pupuk fosfat berbeda terhadap jumlah buah tanaman cabai (Tabel 1). Pada dosis pupuk SP-36 ebagai sumber fosfat 0 dan $40 \mathrm{~g}$ tanaman $^{-1}$, pengaruh pupuk kandang ayam lebih baik masing-masing 5,98\% dan 6,74\% daripada pupuk kandang sapi dan kambing (Tabel 1). Pada pupuk kandang sapi, setiap peningkatan pupuk SP-36 sebagai sumber fosfat sebanyak $5 \mathrm{~g}_{\text {tanaman }}{ }^{-1}$ meningkat jumlah buah sebesar 0,7 buah (Gambar 3).

Pemberian pupuk kandang, dosis pupuk fosfat, dan interaksi antara pupuk kandang dengan dosis pupuk fosfat berbeda terhadap diameter (Tabel 1). Pada dosis pupuk SP-36 sebagai sumber fosfat 0 dan $10 \mathrm{~g}$ tanaman${ }^{1}$, pengaruh pupuk kandang ayam lebih baik masingmasing 2,77\% dan 3,10\% daripada pupuk kandang sapi dan kambing (Tabel 1). Pengaruh pupuk kandang sapi dan kambing tidak berbeda (Tabel 1). Pada pupuk kandang sapi dan kambing, setiap peningkatan dosis pupuk SP-36 sebagai sumber fosfat sebanyak $5 \mathrm{~g}$ tanaman $^{-1}$ meningkat diameter buah sebesar $0,0028 \mathrm{~cm}$ dan 0,0028 cm (Gambar 4).

Pemberian pupuk kandang dan dosis pupuk fosfat memberikan pengaruh pada panjang buah tanaman cabai, sedangkan interaksi antara jenis pupuk kandang dengan dosis pupuk fosfat tidak berpengaruh (Tabel 1). Pemberian pupuk kandang ayam lebih baik daripada pemberian pupuk kandang sapi dan kambing sebesar $6,83 \%$ (Tabel 1).
Pemberian pupuk kandang, dosis pupuk fosfat, dan interaksi antara pupuk kandang dengan dosis pupuk fosfat berbeda terhadap buah tanaman cabai (Tabel 1 dosis pupuk SP-36 sebagai sumber fosfat 20; 30; dan $40 \mathrm{~g} \mathrm{tanaman}^{-1}$, pengaruh pupuk kandang ayam lebih baik masing-masing 5,30\%; 9,36; dan 10,74\% daripada pupuk kandang sapi dan kambing (Tabel 1). Pengaruh pupuk kandang sapi dan kambing tidak berbeda (Tabel 1). Pada pupuk kandang sapi, setiap peningkatan dosis pupuk SP-36 sebagai sumber fosfat sebanyak 5/tanaman meningkatkan bobot buah tanaman cabai sebesar 1,3 $\mathrm{g}$ (Gambar 5).

Pemberian pupuk kandang dan dosis pupuk fosfat tidak memberikan pengaruh pada buah gugur tanaman cabai sedangkan interaksi antara jenis pupuk kandang dengan dosis pupuk fosfat tidak berpengaruh (Tabel 1). Pengaruh pupuk kandang sapi dan kambing dibandingkan dengan pupuk kandang ayam sebesar $38,18 \%$ pada variabel buah gugur (Tabel 1).

Hasil korelasi antarvariabel menunjukkan bahwa terdapat korelasi nyata antara seluruh variabel pengamatan kecuali tingkat percabangan dan buah gugur (Tabel 2).

Hasil penelitian menunjukkan bahwa pengaruh pupuk kandang ayam memberikan hasil yang lebih baik terhadap pertumbuhan dan produksi tanaman cabai dibandingkan dengan jenis pupuk kandang sapi dan pupuk kandang kambing pada semua variabel kecuali tingkat percabangan. Hasil penelitian ini sesuai dengan hasil

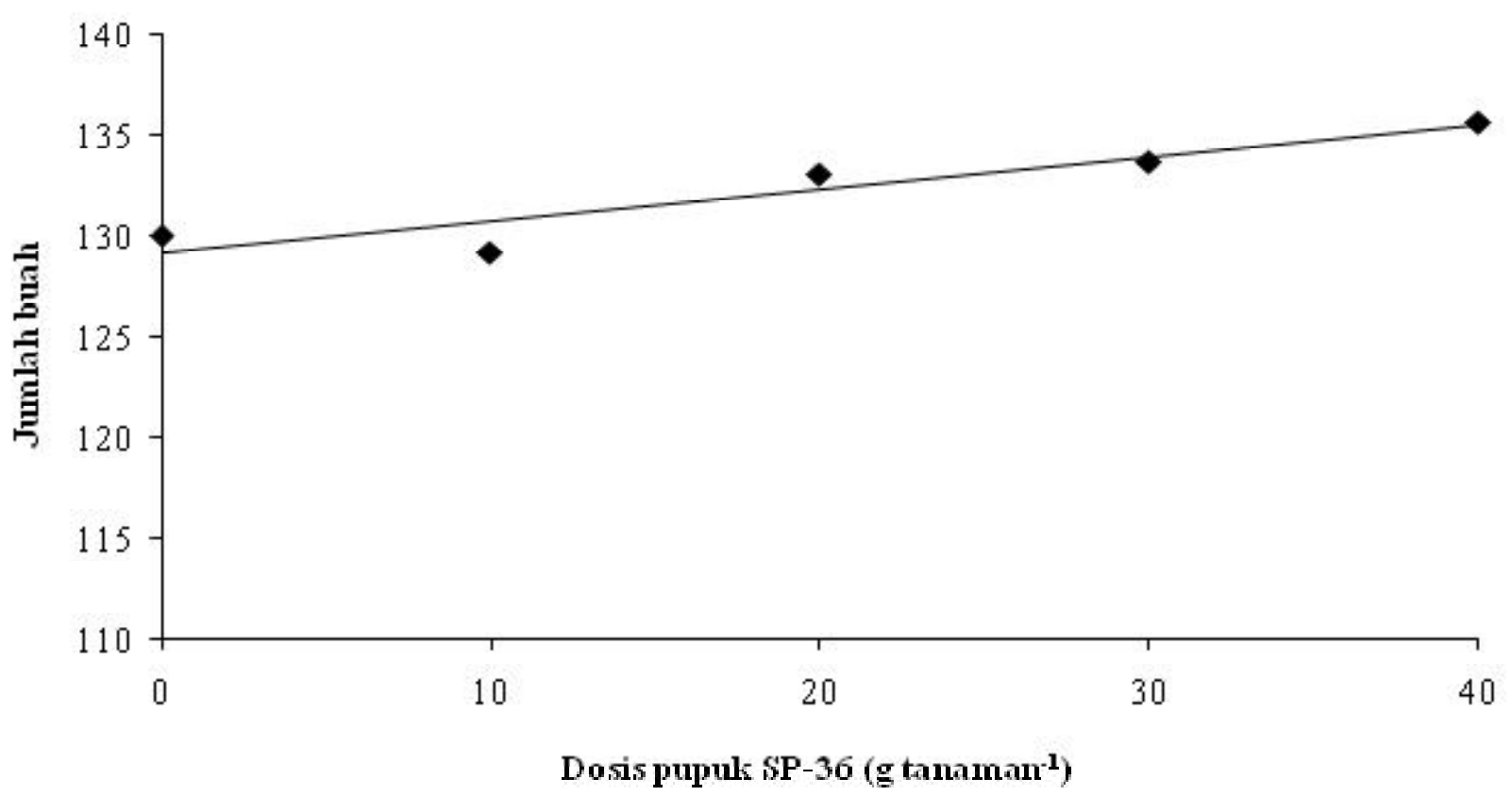

Gambar 3. Pengaruh dosis pupuk SP-36 sebagai sumber fosfat terhadap jumlah buah tanaman cabai pada pupuk kandang sapi. $\left(\mathrm{v}=0,7 \mathrm{x}+129,1, \mathrm{r}=0,93^{*}\right)$. 


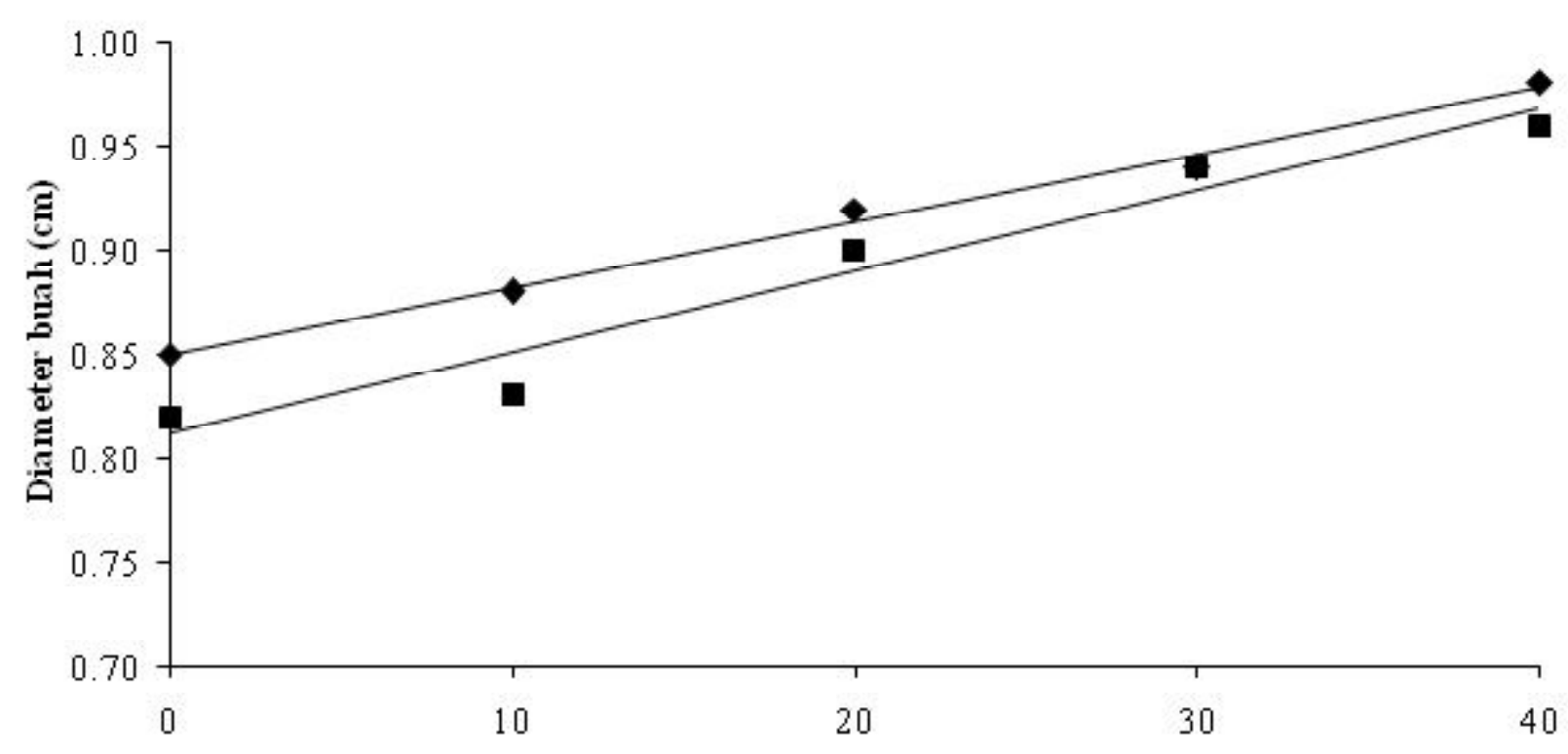

Dosis pupuk SP-36 (g tanaman')

Gambar 4. Pengaruh dosis pupuk SP-36 sebagai sumber fosfat terhadap diameter buah tanaman cabai pada masing-masing pupuk kandang ayam dan kambing. $\boldsymbol{\nabla}=$ pupuk kandang ayam $(\mathrm{Y}=0,0028 \mathrm{x}+0,9573$, $\left.\mathrm{r}=0,96^{*}\right)$ dan $=$ pupuk kandang $\operatorname{kambing}\left(\mathrm{Y}=0,0028 \mathrm{x}+0,9288, \mathrm{r}=0,71^{*}\right)$.

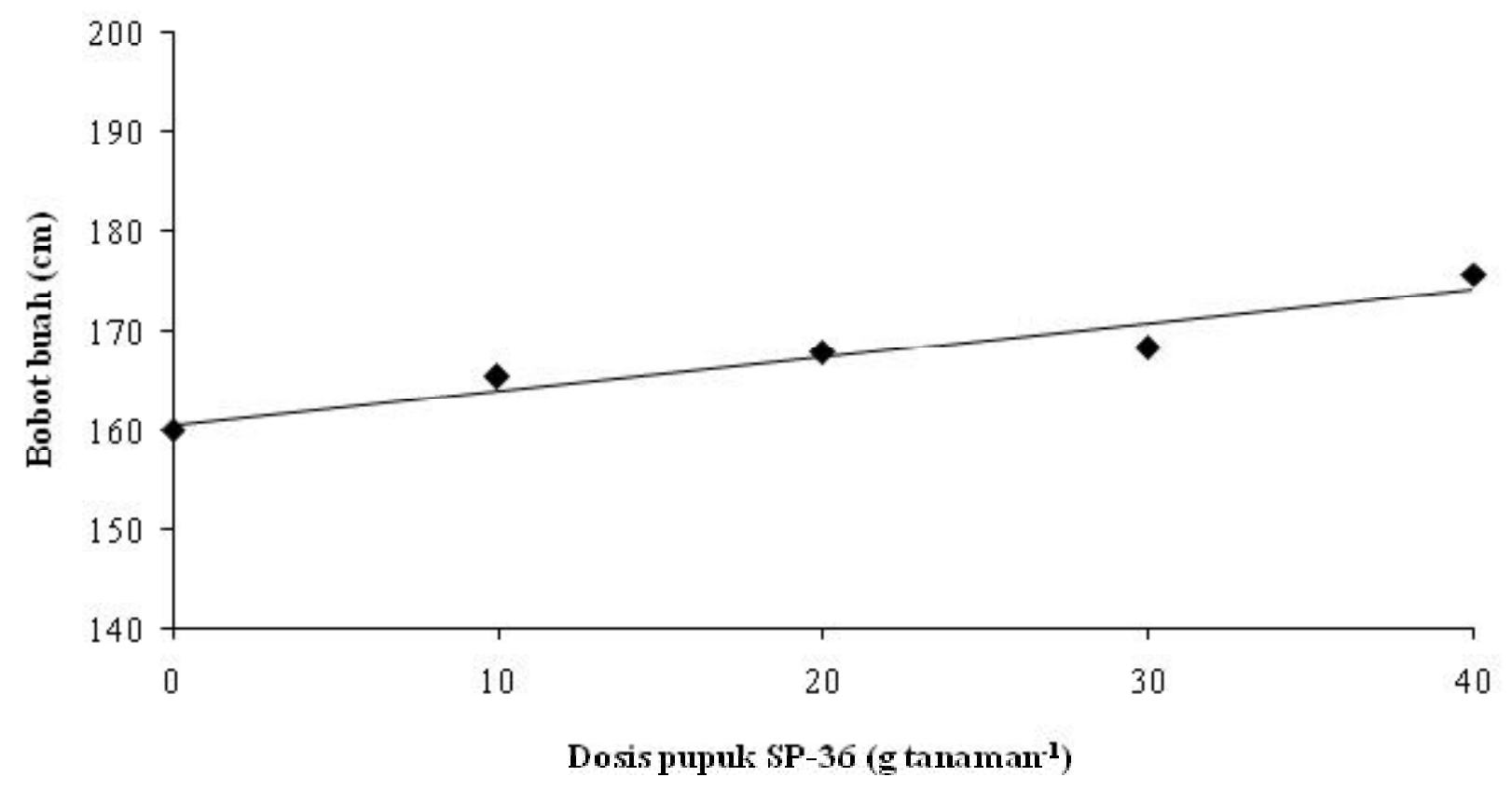

Gambar 5. Pengaruh dosis pupuk SP-36 sebagai sumber fosfat terhadap bobot buah tanaman cabai pada pupuk kandang sapi. $(\mathrm{Y}=1,3 \mathrm{x}+162,96, \mathrm{r}=0,91 *)$.

penelitian Virgundari (2013) yang menunjukkan bahwa pemberian pupuk kandang ayam memberikan hasil yang lebih baik terhadap pertumbuhan dan produksi tanaman cabai pada variabel tinggi tanaman, jumlah bunga, jumlah buah, diameter buah dan bobot buah. Menurut Setiawan
(2005), pupuk kandang ayam merupakan pupuk yang cepat terdekomposisi dibandingkan dengan pupuk kandang sapi dan pupuk kandang kambing, sehingga unsur hara dalam pupuk kandang ayam tersebut cepat tersedia bagi tanaman. Hal ini disebabkan oleh 
Tabel 2. Korelasi antar variabel pengamatan

\begin{tabular}{|c|c|c|c|c|c|c|c|c|c|}
\hline $\begin{array}{c}\text { Variabel } \\
\text { pengamatan }\end{array}$ & $\begin{array}{c}\text { Tinggi } \\
\text { tanaman }\end{array}$ & $\begin{array}{l}\text { Tingkat } \\
\text { cabang }\end{array}$ & $\begin{array}{c}\text { Bobot kering } \\
\text { brangkasan }\end{array}$ & $\begin{array}{c}\text { Jumlah } \\
\text { bunga }\end{array}$ & $\begin{array}{l}\text { Jumlah } \\
\text { buah }\end{array}$ & $\begin{array}{l}\text { Diameter } \\
\text { buah }\end{array}$ & $\begin{array}{l}\text { Panjang } \\
\text { buah }\end{array}$ & $\begin{array}{l}\text { Bobot } \\
\text { buah }\end{array}$ & $\begin{array}{l}\text { Buah } \\
\text { gugur }\end{array}$ \\
\hline Buah gugur & $0,47^{*}$ & $0,23 \mathrm{tn}$ & $0,47 *$ & $0,35 *$ & $0,36^{*}$ & $0,49 *$ & $0,57 *$ & $0,39 *$ & 1,00 \\
\hline Bobot buah & $0,77 *$ & $0,50 *$ & $0,77 *$ & $0,69 *$ & $0,74^{*}$ & $0,64 *$ & $0,70^{*}$ & 1,00 & \\
\hline $\begin{array}{l}\text { Panjang } \\
\text { buah }\end{array}$ & $0,70^{*}$ & $0,44^{*}$ & $0,70 *$ & $0,70^{*}$ & $0,71 *$ & $0,73 *$ & 1,00 & & \\
\hline $\begin{array}{l}\text { Diameter } \\
\text { buah }\end{array}$ & $0,62 *$ & $0,53^{*}$ & $0,62 *$ & $0,51 *$ & $0,52 *$ & 1,00 & & & \\
\hline Jumlah buah & $0,73 *$ & $0,38 *$ & $0,73^{*}$ & $0,97 *$ & 1,00 & & & & \\
\hline $\begin{array}{l}\text { Jumlah } \\
\text { bunga }\end{array}$ & $0,73 *$ & $0,38^{*}$ & $0,67 *$ & 1,00 & & & & & \\
\hline $\begin{array}{l}\text { Berat kering } \\
\text { brangkasan }\end{array}$ & $1,00^{*}$ & $0,52^{*}$ & 1,00 & & & & & & \\
\hline $\begin{array}{l}\text { Tingkat } \\
\text { cabang }\end{array}$ & $0,52^{*}$ & 1,00 & & & & & & & \\
\hline $\begin{array}{l}\text { Tinggi } \\
\text { tanaman }\end{array}$ & 1,00 & & & & & & & & \\
\hline
\end{tabular}

Keterangan: $*=$ nyata pada taraf $\alpha=0,05$, tn $=$ tidak nyata pada taraf $\alpha=0,05$, r-tabel ${ }_{0,05}=0,29$.

perbandingan karbon dan nitrogen $(\mathrm{C} / \mathrm{N})$ sudah cukup rendah walaupun masih dalam bentuk kotoran sehingga tidak diperlukan waktu yang terlalu lama untuk mengalami proses penguraian.

Hasil penelitian menunjukkan bahwa buah gugur akibat pengaruh pemberian pupuk kandang sapi dan pupuk kandang kambing lebih banyak daripada buah gugur tanaman cabai yang diberi pupuk kandang ayam (Tabel 1). Menurut Warsito, dkk. (2003), salah satu penyebab gugur buah tanaman cabai dapat disebabkan kurangnya unsur $\mathrm{P}$ di dalam jaringan tanaman. Keadaan ini disebabkan unsur $\mathrm{P}$ secara fisiologis dapat memperbesar dan memperkuat jaringan tangkai buah serta memperkuat absician layer sehingga berpengaruh terhadap kekuatan tangkai buah tanaman. Menurut Zulaikha dan Gunawan, (2006), apabila tanaman kekurangan fosfor maka hasil fotosintesis yang berupa glukosa tidak dapat disintesis menjadi sukrosa dan diedarkan ke seluruh bagian tanaman melalui floem sehingga pertumbuhan terhambat. Pada hasil analisis pupuk kandang yang telah dilakukan tercantum bahwa kandungan $\mathrm{P}$ yang terdapat pada pupuk kandang ayam lebih tinggi dibandingkan dengan pupuk kandang sapi dan kambing sebesar 2,49\%, 0,63\%, dan 0,71\%.

Hasil penelitian menunjukkan bahwa pemupukan berbagai dosis fosfat secara bersamaan dengan ketiga jenis pupuk kandang meningkatkan pertumbuhan tanaman cabai secara linear pada tingkat percabangan tanaman cabai (Gambar 1). Hal ini sesuai dengan hasil penelitian Nurlenawati, dkk. (2010) yang menunjukkan bahwa pemberian berbagai dosis pupuk $\mathrm{P}$ mampu meningkatkan pertumbuhan tanaman cabai secara linear pada variabel tinggi tanaman dan jumlah cabang tanaman cabai. Menurut Sudjoko dan Sunaryono (1995), keunggulan tanaman cabai TM-999 antara lain, mampu beradaptasi dengan lingkungan dengan baik, memiliki kemampuan untuk tumbuh tinggi dan mampu membentuk percabangan yang banyak. Hardjowigeno (1995) mengemukakan bahwa pemupukan fosfor dapat merangsang metabolisme dan pertumbuhan tanaman, awal bibit tanaman, pembentukan bunga, buah, dan biji.

Hasil penelitian menunjukkan bahwa pemupukan berbagai dosis fosfat secara bersamaan dengan ketiga pupuk kandang meningkatkan kuantitas dan kualitas hasil tanaman cabai secara linear terlihat pada jumlah bunga, jumlah buah, diameter buah, dan bobot buah (Gambar 2, 3, 4, dan 5). Hal ini didukung oleh hasil penelitian Deviani dan Saputra (2009) yang menunjukkan bahwa hasil tanaman cabai meningkat seiring peningkatan dosis pupuk fosfat pada jumlah buah, tetapi bertentangan dengan hasil penelitian Nurlenawati, dkk. (2010) yang menunjukkan pemberian berbagai dosis pupuk fosfat tidak berbeda terhadap diameter buah. Nurlenawati, dkk. (2010) menduga hal ini terjadi disebabkan diameter buah lebih dipengaruhi faktor genetik dibandingkan dengan faktor lingkungan. Sebagaimana pendapat Lingga (1999) bahwa tanpa pemberian pupuk anorganik, maka penambahan pupuk organik akan tidak efektif karena kandungan unsur hara dalam pupuk kandang (organik) masih relatif kecil sehingga perlu menggunakan pupuk anorganik. 
Hasil analisis korelasi antarvariabel menunjukkan bahwa terdapat hubungan antarseluruh variabel pengamatan kecuali tingkat percabangan dengan buah gugur (Tabel 2). Hal ini diduga disebabkan adanya faktor lingkungan yang mempengaruhi jumlah buah gugur seperti buah gugur akibat serangan hama. Buah gugur juga dipengaruhi oleh jumlah buah, semakin banyak jumlah buah semakin banyak jumlah buah gugur. Hal ini belum diketahui pasti penyebabnya, tetapi dapat diduga kekurangan unsur hara mempengaruhi buah gugur tanaman cabai. Penyebab terjadinya buah gugur tanaman cabai pada umumnya antara lain hama dan penyakit, ketersediaan air, suhu tinggi, dan kurangnya hara kalium dan fosfor bagi tanaman (Prajnanta, 2007).

\section{KESIMPULAN}

Hasil penelitian menunjukkan bahwa (1) pengaruh pupuk kandang ayam lebih baik dibandingkan dengan pupuk kandang sapi dan pupuk kandang kambing untuk semua variabel pengamatan, pengaruh pemberian pupuk kandang sapi tidak berbeda dengan pupuk kandang kambing, (2) pengaruh pupuk fosfat hingga dosis $40 \mathrm{~g}$ tanaman $^{-1}$ mampu meningkatkan pertumbuhan dan produksi tanaman tanaman cabai secara linear pada seluruh variabel pengamatan, (3) terdapat pengaruh interaksi pupuk kandang ayam dengan dosis pupuk fosfat, pada tinggi tanaman dan bobot kering brangkasan dosis 10, 30, dan $40 \mathrm{~g}$ tanaman $^{-1}$, pada jumlah bunga dan jumlah buah dosis 0 dan $40 \mathrm{~g}^{-1 a n a m a n}{ }^{-1}$, pada diameter buah dosis $0,10,20$, dan $40 \mathrm{~g}$ tanaman $^{-1}$, dan pada bobot buah dosis 20, 30, dan $40 \mathrm{~g}_{\text {tanaman }}{ }^{-1}$.

\section{DAFTAR PUSTAKA}

Badan Pusat Statistik. 2011. Statistical Yearbook of Indonesia. BPS. Jakarta. $7 \mathrm{hlm}$.

Deviani, D. dan A. Saputra. 2009. Evaluasi hasil dan komponen hasil cabai merah (Capsicum annum L.) pada ultisol dengan beberapa perbedaan dosis CMA, pupuk P, dan $\mathrm{GA}_{3}$. Jurnal Agronomi. 13 (2): 24-30.
Hardjowigeno, S. 1995. Ilmu Tanah. Akademik Pressindo. Jakarta.

Islami, T. dan W. H. Utomo. 1995. Hubungan Tanah, Air, dan Tanaman. IKIP Semarang Press.

Lingga, P. 1999. Petunjuk Penggunaan Pupuk. Penebar Swadaya. Jakarta.

Madjid, A. 2007. Dasar-dasar Ilmu Tanah. Bahan kuliah online Fak. Pertanian UNSRI. http:// dasar2ilmutanah.blogspot.com/2007/11/kapasitastukar kation-ktk.html. Diakses 24 Desember 2012.

Nurlenawati, N., A. Jannah., dan Nimih. 2010. Respon pertumbuhan dan hasil tanaman cabai merah varietas prabu terhadap berbagai dosis pupuk fosfat dan bokashi jerami limbah jamur merang. Jurnal Agrika. 4(1):9-20.

Prajnanta, F. 2007. Agribisnis Cabai Hibrida. Penebar Swadaya. Jakarta.

Setiawan. 2005. Budi Daya dan Pengaturan Panen Sayuran Dataran Tinggi. Penebar Swadaya Jakarta.

Sudjoko, S. dan H.Sunaryono. 1995. Varietas Kentang dan Pemeliharannya. Lembang. Jawa Barat.

Virgundari, S. 2013. Pengaruh Tiga Jenis Pupuk Kandang terhadap Pertumbuhan dan Produksi Tanaman Cabai (Capsicum annum L.) yang Dipupuk $\mathrm{KCl}$ Berbagai Dosis. Skripsi. Universitas Lampung.

Warsito, M., M. Baiq., dan M. Santoso. 2003. Respons tanaman cabai merah terhadap pupuk $\mathrm{P}$ dan Beberapa ZPT. Laporan Penelitian. UNMUL.

Zulaikha, S. dan Gunawan. 2006. Serapan fosfat dan respon fisiologis tanaman cabai merah Cultivar hot beauty terhadap mikoriza dan pupuk fosfat pada tanah Ultisol. J. Bioscientiae. 3(2):83-92. 